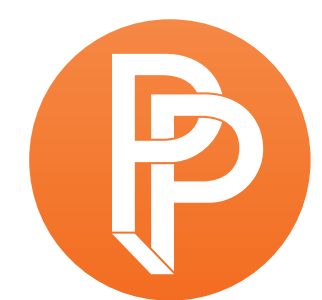

PERFORMANCE

PHILOSOPHY

\title{
THE CONTEMPORARY QUARREL BETWEEN PERFORMANCE AND LITERATURE? REFLECTIONS ON PERFORMANCE(AND) PHILOSOPHY
}

\author{
JAMES CORBY UNIVERSITY OF MALTA
}

Introduction

The title of this paper alludes, of course, to the famous reference in Book X of Plato's Republic to the 'ancient quarrel between poetry and philosophy'. ${ }^{1}$ It is a significant formulation for many reasons, not least because it seems to mark in a memorable way a defining insight into the originary self-understanding of philosophy, wherein philosophy defines itself through its opposition to poetry because of their purportedly differing relations to truth - philosophy serving truth directly, poetry having, at best, a secondary or ancillary relationship to truth, and, at worst, a distorting or obscuring one. It is this conviction that has Plato exclude poets from the polis. Of course, it has long been recognised that there is a certain degree of self-deception in this thumbnail sketch of philosophy's self-understanding. The Platonic dialogues are in many ways very obviously literary, and much subsequent philosophy has sought to explore and even exploit this proximity to the poetic. Similarly, it can be argued that from Romanticism onwards an important characteristic of modernity has been the renegotiation of poetry's relationship with truth, with an emphasis, typically, on rejecting Platonic metaphysics and establishing some sort of philosophical efficaciousness for poetry and art more generally.

But what is 'the contemporary quarrel between performance and literature' that the title of this essay directly names_even if, given the question mark, only as a hypothetical possibility—and 
what does it have to do with the ancient quarrel between philosophy and poetry? This is what the two argumentative movements in this article will attempt to make clear. What motivates these arguments is a conviction that there exists an equation, or strong commonality, between poetry as it was conceived by the ancients, literature as it was theorised in the latter half of the twentieth century, and performance as it might be understood today. First, it will be argued that from our perspective it is more appropriate to understand the ancient quarrel as being between philosophy and performance. Second, it will be proposed that the principle of performance that Plato objected to is at the heart of an influential contemporary understanding of literature, and that it is what is often identified as characterising literature's radical potential and appeal-an appeal that can be seen particularly clearly in the way literature was figured in the linguistic turn in the humanities and the theory explosion of the 1960s and 1970s. What ultimately undergirds this shifting confluence of terms is something that we might call the principle of performance, which poetry, performance, literature, and even philosophy, have, at various times and to varying degrees, accommodated and celebrated. In conclusion, it will be asked how well the emergent movement of Performance Philosophy might be expected to accommodate this principle of performance and whether, in fact, as might be suspected, it risks re-inscribing, reiterating, perhaps even re-citing, philosophy's foundational rejection of the principle of performance.

\section{The ancient quarrel between philosophy and performance}

Plato famously considered poetry dangerous, a threat to truth, because it is mimetic. Without further elaboration this sort of statement tells us very little and might even be unintentionally misleading. It certainly does not translate particularly intuitively to our experience of poetry. What, for instance, is T.S. Eliot's The Waste Land imitative of, and why would we consider it a threat? Moreover, although there is a long tradition of politically subversive poetry, is there anything today less threatening to the political status quo than poets and poetry? Part of the difficulty, I think, lies in the fact that although 'poetry' is an accurate lexical translation of poiétike, the word that Plato uses, it, on its own, does not do the work of cultural and conceptual translation that is needed to avoid potential misunderstandings. The word poiētikē is derived from the word poiettai, meaning literally 'the art of the poiētai' (Nagy 2010, 378), who were composers and often performers of mousike, the art of the muses, which covers the various media of poetry and song and dance and instrumental music' (371). Mousike, from which we get the word 'music', is sometimes rendered as 'poetry' in English translations of Plato (see, for example, Ferrari 1989, 92, fn. 1), and this slippage is indicative. As G.R.F. Ferrari observes, 'In Plato's culture, live performance was the norm' (Ferrari 1989, 92). What is referred to as 'poetry' would typically have involved music and dance as well, and citizens would have experienced it either as members of an audience or, indeed, as performers themselves. Ferrari makes this point wryly clear when he says that 'in order to gauge Plato's critique we must first banish any image of the serious reader curled quietly in an armchair with the lliad' (93). In light of this relatively uncertain cultural terrain, it is essential to reconstruct carefully Plato's arguments against poetry. In doing so, it should become clear that what is objected to is closer to what today we would understand as performance, particularly performance as it is understood and experienced in the 
age of postdramatic theatre. From this, it will be argued that it is possible to identify what might be called a principle of performance.

One of the first things to note is that Plato, or Socrates, identifies an acceptable use of mimesis as well as an unacceptable use, and their difference is instructive. In their purest form, Socrates suggests, there are two narrative styles (Plato 2003, 392c-d, 396b-c, 397b). The first-most simple-kind is what today would be understood as third-person narration, where, as Socrates puts it, 'the poet speaks in person [and] does not attempt to direct our imagination towards anyone else, or suggest that someone other than himself is speaking'. The second kind, which today might be understood as imitative performance, is where the poet imitates someone-or something-and 'does everything he can to make us imagine' that it is no longer the poet speaking (393a-b). The distinction between the two types of narration is broadly that of diegesis and mimesis, though whereas those modes might typically be thought of in terms of text-bound literary conventions, for Plato the act of performative dissimulation required by mimesis would involve much more than mere syntactical effects. The move from diegesis to mimesis would be a move from a narrow and restrained mode of delivery to something much more fully enacted, which might incorporate, for instance, non-verbal sounds, physical gestures, mannerisms, costumes, music, rhythm and so on. Plato sees a complex moral, political, psychological and philosophical dimension to these narrative styles, and there can be no doubt that he judges the second form of narrative negatively.

Typically, a poet would draw on both styles, mixing them together to varying degrees, and this allows Socrates to make an important distinction between the acceptable and unacceptable uses of imitation. There are two broad tendencies: first, the tendency to use imitation very sparingly and only when what is to be imitated is admirable, edifying, or at the very least morally sound; second, the tendency to use imitation indulgently, copying anything and everything, doing so without restriction, and using all manner of tricks to that effect. The first will appeal to what Plato, or Socrates, calls the 'decent man', who, because of his nature, will imitate only the 'saying or action of a good man', refusing to imitate someone acting in an unworthy or disreputable manner (Plato 2003, 395c). This approach to storytelling will result in a combination of third person narrative and imitative performance weighted very heavily towards the former. As Socrates puts it: '[t]he way he tells stories will combine both styles, imitation and the other kind of narrative, but with only a small amount of imitation even in a long story' (396e). But this is not simply a question of the quantity of imitative performance, but the quality of it too: it will be limited in range and scope according to what is appropriate for a 'decent man' (which in turn connects it with 'truth').

The second approach, in contrast, appeals to the sort of person who is 'not of this sort', that is, not decent. 'The worse he is', argues Socrates, 'the more prepared he will be to use imitation all the time' (Plato 2003, 397a); or, as an alternative version of Plato's text yields the translation, 'the more prepared he will be to narrate anything and everything' (Plato 1998, 397a). Socrates goes on: 
There is nothing he will regard as beneath him, and so he will take it upon himself, in all seriousness, and at public performances, to imitate all the things we were talking about just now - thunder, the din of wind and hail, of wheels and pulleys, the sound of trumpet, pipe, panpipe, and every musical instrument, even the noise of dogs, or sheep, or birds (Plato 2003, 397a-b).

Socrates asks: 'Will the way this man tells stories consist entirely of imitation, in word and gesture, with maybe a small element of narrative?' His interlocutor replies that 'it's bound to' (397b).

Socrates thereby establishes 'two styles of storytelling', both involving mimesis, but only one of which he considers acceptable in the ideal city-state he envisages. The first, the mode appropriate to the decent man, is limited in range and 'involves only slight variations'. The other, '[b]ecause of the enormous range of variations it contains' draws on 'all the musical modes, and every kind of rhythm' (397b-c). This sort of multi-faceted, unrestricted, all-out performance is not 'in tune' with the political regime Socrates subscribes to, where men 'do not have a dual or manifold nature, since each of them performs only one task' (397e). Therefore this latter kind of poet ought not to be allowed in the city, even though his art is, Socrates admits, 'by far the most enjoyable' (397d). This in itself is very interesting as it points to a particular tension: namely that for imitative performance to be politically, morally and philosophically acceptable, its tendency to develop freely into a more fully performative mode of expression, a tendency otherwise encouraged by audiences who take pleasure in it, must be restricted. What is being objected to, then, is, from a twenty-first century perspective, perhaps not so much 'poetry', or even 'imitation' per se, but rather something we might call, as yet rather vaguely, unrestricted performance.

This seems a long way from the famous discussion in Book $X$ that uses the rather unhelpful example of furniture-making to indict the mimetic arts. Even this, however, can be read in such a way as to yield support for the idea that what is being objected to is, first and foremost, the general lack of restriction that performance represents. Socrates asserts that the craftsman does not create the real couch or bed; he creates '[s] omething like the real thing, but not itself the real thing'. It remains, he says, somewhat 'shadowy by comparison with truth' (Plato 2003, 597a-b). However, the suggestion is that the craftsman's bed is a higher order form of imitation than, for instance, a painting of a bed. This is usually quickly grasped as meaning that the painter's bed is no more than a copy of the craftsman's own copy, thus situating the painter's bed at 'two removes from nature' (597e). It is not simply a copy of an original, then, but a copy of a copy. But, one might ask, could the painter not be copying the original idea or form of a bed rather than the craftsman's imperfect realisation of that idea? In other words, why must the painter's realisation of a bed be further removed from truth than the craftsman's? The answer to this perhaps concerns a difference in the realisation of both beds in relation to what one might call the 'enduser'. The craftsman creates the bed with knowledge of how the bed will be used. This is a skill developed over time by listening to what the people who acquire and use his furniture tell him. If the idea of a bed dictates that it should serve a particular function and have particular qualities, then the end-user will be able to provide feedback on how successfully realised as a bed the 
craftsman's is. This means that the craftsman accumulates a knowledge-or a 'correct opinion'about what, in this context, is a good bed, or even a true bed (601e-602a). The craftsman's imitations are, therefore, informed by knowledge.

The great mistake and great danger, Socrates believes, is to think that the mimetic arts are similarly informed by knowledge. In order to understand his point, it is worth thinking about what the relationship of, say, the painter is to the end-user of his imitation. The end-user, the person experiencing the painting of the bed, does not, of course, experience the bed as a bed. He or she experiences it as a representation. The painter therefore has licence to present the painting of the bed to the end-user in a manner that is not influenced or restricted by considerations about the end-user as a bed-user. In other words, what the painter of the bed picture appeals to in the end-user is not the knowledge and experience of a bed-user - at least, typically, not first and foremost. It is possible to imagine painterly representation restricted by considerations that would affect a bed-user qua bed-user. The resulting image might appeal to end-users interested in the craftsmanship of beds and who possess a rather limited appreciation of painting, but it is unlikely to satisfy the intended end-user-who is not primarily a bed-user, but rather someone who takes pleasure in representations. This becomes even clearer if, rather than thinking about the craftsman who makes a bed in relation to the painter who paints one, we think instead of the same craftsman in relation to an artist, a sculptor, let us say, who is representing a bed in the medium of wood. Both are representing a bed and both are using wood in order to do so. The craftsman, however, is restricted by his knowledge of what makes a good bed intended to be used as a bed. The artist, on the other hand, does not suffer the same restriction as she is appealing to an audience that will experience the bed as an artwork-something not to be used as a bed but rather to be enjoyed aesthetically. Of course, there are still restrictions of taste and convention that may influence the artist's rendering of the bed, but generally, by Socrates' own admission, we take most pleasure in art that flouts convention and taste and is allowed to develop freely under its own impetus and according to its own nature-autotelically and autonomously, we might say.

So, on this reading, the decoupling of the mimetic arts from knowledge, correct opinion, truth and so on, should be understood as a certain kind of freedom. Socrates, indeed, refers to it as 'a kind of play' (602b). However it is still unclear why this kind of imitation-think of Van Gogh's Bedroom in Arles paintings, or Tracy Emin's My Bed-should be considered threatening. This is where the example of furniture is decidedly unhelpful. The stakes become clearer, however, if rather than thinking of a bed, one applies the same ideas to something like human virtue, for instance. Unrestricted imitative performance, freed from any responsibility to a priori ideas of truth, can present what might otherwise be considered inappropriate human behaviour in a beguiling and pleasurable way, thereby undermining and questioning received ideas about human virtue.

This once again brings us to the question of the end-user. If the success of the artistic imitation does not depend on its relationship with a priori conceptions of knowledge and truth, then on what other basis might it be considered successful? In other words, to what in us does this kind 
of play appeal? What is it that disposes us to bracket or reconfigure what we might consider to be a correct opinion about the world in order to entertain other possibilities? To answer this question one must have an understanding of the nature of man according to Socrates. He suggests that the soul of man is divided into a rational part, which 'puts its trust in measurement and calculation' and is constrained by a conservative tendency that sets great store by custom, and a non-rational part that thrives on more subjective stimuli such as visual and poetic representation, as well as emotionality and affectivity (Plato 2003, 603a). These two parts lead to different behaviours and conclusions about the world depending on which has greatest influence, and they find themselves accommodated by very different styles of poetry. The rational part is inherently resistant to imitation. It is 'hard to imitate, and not a simple matter to understand if it is imitated'; the other, 'fretful', element, by contrast, 'is highly susceptible to all sorts of varied imitation' (604e), and is thus a natural match for a more fully developed form of performance. So there seems to be an inherent conflict between knowledge, reason, truth, custom and imitative performance. Socrates comments that '[t]he imitative poet's nature is obviously not adapted to this element in the soul, nor is his wisdom framed to appeal to it'. If he is going to be 'popular with the general public' he must attend to 'the fretful, variegated character', which is not only more amenable to performance-because it is 'easy [or easier] to imitate'-but it also sets fewest restrictions on his performative art and, indeed, is actually encouraged by the audience's response to exercise itself freely (605a).

Unbounded mimetic performance, then, manifesting a fundamental irresponsibility towards established ideas of knowledge and truth, 'arouses and feeds' what Socrates calls the 'inferior part of the soul' and in doing so 'destroys the rational part' (605b). This is what Socrates (and Plato, one assumes) objects to: a deformation or obscuring of truth as an unintended but, as they would see it, likely consequence of unrestricted performance. Of course, this need not be viewed negatively. Indeed, it is perhaps the fundamental irresponsibility of mimetic performance, its exuberant autotelicity and disclocation from a priori conceptions of truth and knowledge, which makes it valuable as an essentially creative act. It is important to understand the extent and capacity of this creativity. On Socrates' charge, for instance, this distortion or defiguring of the world is a form of fiction (though he has no word for fiction) capable of instituting its own world. The imitation, in other words, has the power to create its own original, and we find this process inherently pleasurable and compelling. Rather than producing a faithful copy, then, exaggerated, unbounded, performative mimesis is sufficiently removed from any a priori model for its productions to be viewed as something new and alternative. This is 'copy' in its original sense of copia, meaning abundance, plenty, multitude, and it stands in opposition to what Derrida called 'mimetologism', 'the interpretation of mimesis as imitation, or even as representation' (LacoueLabarthe 1998, 26). It is mimesis on the side of difference, not on the side of the same. We know how beguiling we ourselves find her', says Socrates, 'But it is wrong to abandon what we believe to be true' $(607 c b-d)$. This is the crux, of course: poetry, when allowed to develop without restriction, assumes all manner of performative expression-rhythm, dance, music, song and so on -and thereby allows us, even encourages us, to move beyond what we believe to be true, reconfiguring the way the world appears to us, redrawing in a different place the dividing line between the possible and the impossible. 
One could substantiate this argument further by drawing on other Platonic works such as Ion and the Laws, but the dialectic of pleasure, subversion and developing performative expression should now be sufficiently clear and understandable as attesting to a quarrel more aptly framed from today's perspective as being between philosophy and performance, rather than between philosophy and poetry. But what exactly might be meant by 'performance' in this context? Is a more precise definition possible? Of course, there are numerous influential accounts of performance given by the likes of Marvin Carlson (1996), Erika Fischer-Lichte (2008), Shannon Jackson (2006), Jon McKenzie (2001), Peggy Phelan (1996), Richard Schechner (2004) and many others, and wealth of scholarship on performativity from J.L. Austin (1962) to Judith Butler $(1997,1999,2011)$. In order to account for what Plato objects to, a simpler, broader definition might, tentatively, be hazarded, whereby performance is simply anything done or experienced intentionally and for its own sake-any deliberate, autotelic act, in other words. On this understanding, although performance might give rise to, say, pleasure, it remains autotelic insofar as that pleasure is integral to the performance, the performance being an expression of that pleasure. This pleasure-using the term broadly—taken in doing something deliberately and for its own sake encourages the development of the doing of that act, a sense of care entwined with the practice. This, in a nutshell, is precisely what Socrates disapproves of. If performance can be limited to serving particular moral, religious and philosophical ends-'telling nothing but medicinal or noble lies' as Stanley Rosen $(1993,3)$ puts it-then it is allowed to remain within the polis. If, however, it is done autotelically, then it is judged dangerous and irresponsible and is excluded. As has already been noted, Socrates calls this kind of autotelicity 'play'. It is unrestricted by external considerations, and any artistic conventions that shape it are expected to evolve through its own experiential development, in a kind of self-regulating, continually active feedback loop. On these grounds one might make the case for a certain autonomy of performance, in addition to its autotelicity. This is not to deny the social situatedness of such performance, simply the fundamental irresponsibility that it embodies. As Adorno puts it in Aesthetic Theory: '[A]rt becomes social by its opposition to society, and it occupies this position only as autonomous art' $(1997,225)$.

\section{Poetry unbound}

Now, this definition is arguably so loose as to accommodate all art, and insofar as an artwork is created or experienced autotelically - a not uncommon modern understanding of art-then it may indeed be granted that such processual production and experiencing do qualify as performance. However, the modern, highly theorised conception of 'literature' is perhaps a particularly exemplary case here. Indeed, one might argue that in the explosion of continental theory in the 1960s and 1970s, which had such an influence upon the humanities in academia, 'literature', or, more especially, the idea of literature, came to stand for this principle of performance-this radically unbounded autotelicity that stages the suspension of what is taken to be truth, knowledge, correct opinion-thereby providing a space in which, without being named as such, that principle could be reaffirmed and further theorised. 
The conditions for the emergence of this conception of literature can be traced back to the early German Romantics, who have been understood as inaugurating a period-one that, arguably, we still occupy-in which poetry assumes and explores a constitutive autotelicity, and where literature is idealised as the institution that preserves and safeguards that principle. Alain Badiou names the epoch in which this regime is operative and preeminent as 'the age of the poets' (2014). In the Athenaeum fragment 116, Friedrich Schlegel characterises 'Romantic poetry' as always being in a 'state of becoming':

\begin{abstract}
that, in fact, is its real essence: that it should forever be becoming and never be perfected. [...] It alone is infinite, just as it alone is free; and it recognises as its first commandment that the will of the poet can tolerate no law above itself. The romantic kind of poetry is the only one that is more than a kind, that is, as it were, poetry itself: for in a certain sense all poetry is or should be romantic (Schlegel 1971, 175-6).
\end{abstract}

Hegel describes this aesthetic autotelicity as art's 'self-transcendence' (Hegel 1975, 607) and Maurice Blanchot, in his essay 'The Athenaeum', claims that with early German Romanticism 'literature' emerges in its radical modern guise, becoming conscious of itself as a discourse that has no proper characteristic other than the ongoing expression of itself in its ceaseless, unrestricted self-becoming:

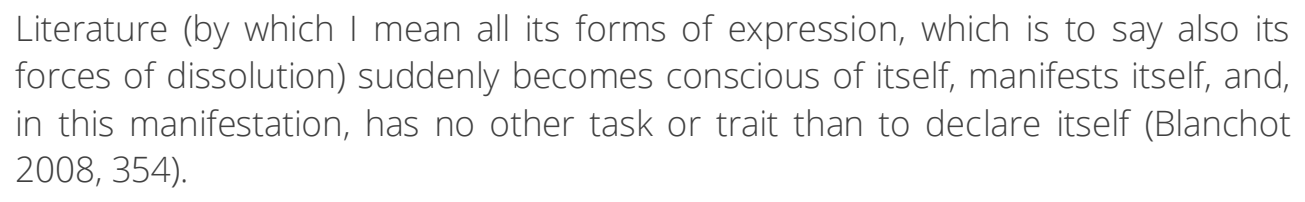

Thus, simply being what it is-that is to say, being nothing besides the boundless potentiality of its own manifestation-literature, thus conceived, is a constant challenge to itself, endlessly undermining what it has been taken to be. '[P]oetry', Blanchot writes, 'will no longer be content to produce beautiful, determinate works, but rather will produce itself in a movement without term and without determination' (354). This 'declarative mode' amounts to an inevitable and unending self-interrogation. It is 'the inexhaustible act that institutes and constitutes the being of literature' (355). Jean-Luc Nancy, also heavily influenced by early German Romanticism (see LacoueLabarthe and Nancy, 1988), develops this idea:

\footnotetext{
'Poetry' does not exactly have a sense; rather it has the sense of an access to a sense that is each time absent, and postponed until later. The sense of 'poetry' is a sense that is always still to be made. [...] Poetry is in essence something more and something other than poetry itself. [...] Poetry does not coincide with itself: perhaps this non-coincidence, this essential improperness or impropriety, is properly what makes poetry what it is (Nancy 2006, 4).
}

Like Blanchot, Nancy draws out the critical implications of this essential creativity, commenting that poetry 'may be deemed what it is only insofar as it is (at the very least) capable of negating itself, in the sense of renouncing, denying or abolishing itself'. Poetry, in its very being, thus 
manifests, or performs, a fundamental irresponsibility or indifference towards established norms: 'By negating itself, poetry denies that the access to sense may be equated with any given mode of expression or figuration' (4).

The parallels with the form of unbounded mimetic performance rejected by Plato should be obvious. Furthermore, it should now also be possible to see that this form of mimesis is simply the manifestation of the logic of mimesis taken to its most extreme-and most coherentconsequence. In fact, if what is being called the principle of performance is determined by anything, it is by a fidelity to the properly improper, or purely impure, truth of mimesis, whereby mimesis cannot be except through the appropriation of that which, properly, it is not. Thus, the minimal constitution of mimesis itself ensures that it is little more than the challenging and undermining of propriety. As Philippe Lacoue-Labarthe points out, 'what is "proper" to mimesis' lies precisely in the fact that 'mimesis has no "proper" to it, ever (so that mimesis does not consist in the improper, either, or in who knows what "negative" essence, but ek-sists, or better yet, "desists" in this appropriation of everything supposedly proper that necessarily jeopardises property "itself')'. Thus, if the 'essence' of mimesis is 'precisely absolute vicariousness, carried to the limit (but inexhaustible)', the principle of performance, in its various guises, is an affirmation of this impropriety (Lacoue-Labarthe 1998, 116).

As has already been indicated, Derrida distinguishes between this understanding of mimesis as an essentially creative and unbounded appropriation ${ }^{2}$ - the form of mimesis rejected by Platoand mimetologism's faithful imitation or representation of pre-existing truths and received ideas. It is through this lens that Rodolphe Gasché attempts to clarify the radical potential of the idea of literature that emerged from Romanticism and then came prominently to the fore with the theory explosion in the humanities in the latter half of the twentieth century. Gasché argues that for most of its history, literature has been something other than literature-or literature only secondarily. He writes that 'Aristotle's production of the concept of literature in the Poetics (in the aftermath of Plato's determination of poetry as mimesis) inaugurates the history of literature as a history in which the certification of literature's birth, the declaration of its name, coincides with its disappearance'. This understanding of literature, forged according to the demands of mimetologism, restricts the principle of performance by enthralling literature to the demands and expectations of philosophy. As Gasché puts it: 'The interpretation of mimesis as subject to truth, as a mimetologism that proclaims the priority and precedence of the imitated over imitation, subjects literature to a status of metaphoric secondariness' (Gasché 1997, 256). One consequence of the Romantic break with this conception of literature was a move to claim for literature something proper to itself-the 'literary', 'literariness' or 'literarity'. But, once again, this would be to impose an ontological restriction upon literature that would require it to manifest literariness in order to be 'itself'. Derrida is clear that 'there is no text which is literary in itself: 'Literarity is not a natural essence, an intrinsic property of the text' (Derrida 2002, 44). Although the impulse to isolate and identify something proper to literature might be understood as being motivated by a rejection of the mimetological conception of literature, it is in fact similarly limiting, subjugating the autotelic play of literature to an idea that exists independently of it. As Derrida writes, the notion of 'pure literature [...] risks limiting the play, restricting it' (Derrida 1976, 
59). Gasché concludes that '[m]imetologism and literarity are the birth and death of literature through philosophy' (Gasché 1997, 257).

It is in this context that the full complexity of Derrida's famous assertion that 'there is no-or hardly any, ever so little-literature' (Derrida 1981, 223) starts to become apparent. Literature, understood without subjection to mimetologism or to formalist ideas of literariness, is little more than the affirmation of the potentially unlimited and inexhaustible invention and development that results from deliberate and autotelic doing, and which I am suggesting can be understood as the principle of performance. In this sense, then, there is very little, almost nothing, that is proper to literature-there is, one might say, nothing to it. But, in another sense, because historically there has been such scant recognition of literature's ontological indigence-fuller philosophical determinations of it having been favoured instead-there is, materially, very little literature worthy of the name. It is precisely this minimally-constituted conception of literature that challenges both philosophy and what, previously, has been considered literature, by being willing to suspend, in its very manifestation, any tenet or practice. Literature, theorised in this way, is a discourse that affirms its readiness to forgo the foregoing in the jouissance of its own autotelicity. This is literature that, in Roland Barthes' words, 'imposes a state of loss, [...] discomforts [...], unsettles the reader's historical, cultural, psychological assumptions, the consistency of his tastes, values, memories, brings to a crisis his relation with language' (Barthes 1998, 14). From this sort of perspective, as Gasché observes, 'Literature becomes a radical interrogation of philosophy, and of most past literature as well, not only by refusing its foundation in a preceding and prior being of meaning but also by disclaiming any formal essence as concerns its substance of expression' (258). Hence Derrida's claim that 'the subversion of logocentrism [is] announced better than elsewhere, today, in a certain sector and certain determined form of "literary" practice' (Derrida 1982, 11). But, of course, if this conception of literature is indeed, as I am arguing, 'simply' the latest manifestation and affirmation of the principle of performance-which Plato himself had perceived as such a threat to what Derrida calls 'logocentrism'-then this should hardly be surprising. The important point, though, is that this critical-indeed, philosophical-capacity of literature is secondary and in no way compromises literature's autotelicity by means of some sort of concession to an instrumentalising critical function. To reiterate Blanchot, literature is interrogative in its declarative mode-a declarativity without restriction. It is for this reason that Derrida identifies a fundamental co-dependence between 'literature' (understood, of course, in this very particular way) and democracy:

\footnotetext{
Literature is a modern invention, inscribed in conventions and institutions which, to hold on to just this trait, secure in principle its right to say everything. Literature thus ties its destiny to a certain noncensure, to the space of democratic freedom (freedom of the press, freedom of speech, etc.). No democracy without literature; no literature without democracy (Derrida 1995, 28).
}

Literature, for Derrida, then, is thus 'the institution which allows one to say everything, in every way': 
The space of literature is not only that of an instituted fiction but also a fictive institution which in principle allows one to say everything. To say everything is no doubt to gather, by translating, all figures into one another, to totalise by formalising, but to say everything is also to break out of [franchir] prohibitions. To affranchise oneself [s'affranchir] - in every field where law can lay down the law (Derrida 1992, 36).

This critical, performative autotelicity of literature is compellingly articulated by Derek Attridge in his essay 'Singular Events: Literature, Invention, and Performance' (2002) and, subsequently, in The Singularity of Literature (2004). Attridge identifies the 'peculiar potency of literature' as attributable to its 'singularity and inventiveness'. Here, '[s]ingularity names the quality whereby a cultural object of a certain kind differs from all others, not as a particular manifestation of general rules but as a uniqueness perceived as resisting or exceeding all general determinations'. Whereas '[i]nventiveness is [...] the capacity of a cultural product to bring about a refashioning of the norms and habits on which we regularly rely in our understanding of such products' (2002, 50). Literature, then, would be understood as an event of singularity and inventiveness, which, crucially, Attridge insists, is experienced 'as event'. 'Another way of putting this', Attridge writes, 'is that the literary text exists, as literary text, only in performance'. He suggests that he chooses 'the term performance because it points to that element of self-distance that is present in the event of the literary, the event comprehended in its eventness' (56). I take this to be an affirmation of literature's autotelicity, whereby it is experienced deliberately and for its own sake. This is what sets literature apart from every other use of language:

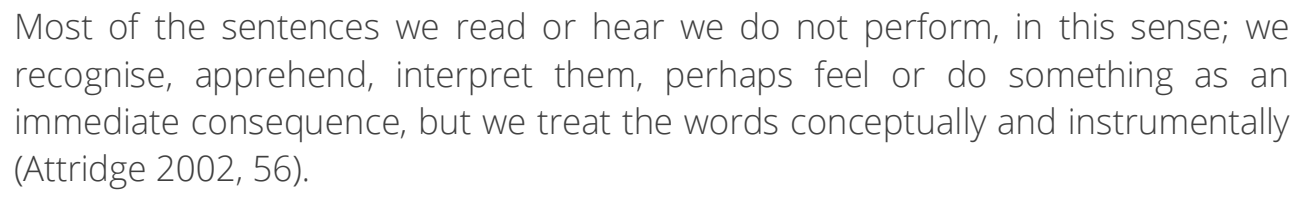

As such, language used in this way remains restricted by the pre-existence of the world in which it finds itself and which it serves. The performance of singularity in the event of literature, on the other hand, manifests the fundamental irresponsibility of the principle of performance and, in doing so, 'it disjoins the cultural matrix to the point of allowing alterity to arise' (Attridge 2002, 59). Derrida names this the 'duty of irresponsibility', which, he says, 'is perhaps the highest form of responsibility' (Derrida 1992, 38). And if literature is the institution that, in principle, allows everything to be said, then poetry might be considered-and often has been-the mode in which that radical freedom has been articulated most potently. As David Constantine has put it:

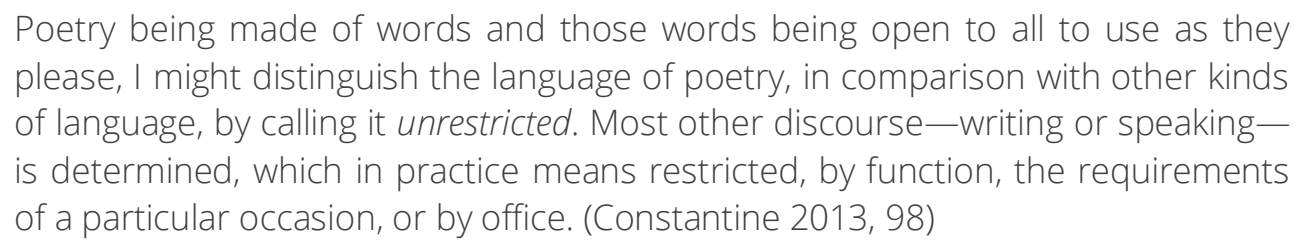

In this light, both performance, as defined through Plato, and literature, understood in the age of high theory, seem to assert and safeguard a certain principle of heterogeneity. Literature, of 
course, evidently lacks many of the characteristics we associate with performance, such as liveness, embodiment, witnessing, participation, and so on, but all of these things can be seen simply as mechanisms for intensifying the various tensions that might emerge between the autotelic act or experience and the social, cultural and political environment in which they occur. It is in those tensions-the condition of the possibility of which is the deliberately autotelic act (the principle of performance, in other words)-that performance, and indeed performativity, finds its evental potential. For all of the heterogeneity of unbounded performance, performativity itself ultimately remains bound within the horizon of the possible (see Derrida 2002, 234-5). It is in the tension between the performance and its social, cultural, political environment that eventality becomes possible.

\section{The contemporary quarrel between performance (philosophy) and literature?}

The heady days of high theory, and its idealisation of literature as the discourse which must supplement or even supplant philosophy, have, of course, long-since receded. The onceprevalent belief in a rapprochement in both theory and practice between philosophy and the principle of performance in a particular conception of literature came to seem like a gloriously improbable dream. The movement identified as Performance Philosophy, however, seems to announce a new attempt at suturing the originary rupture between philosophy and performance. It offers a framework for investigating performance as 'the dramatic embodiment of ideas' and as 'the event of thinking [...] inscribed in flesh and voice's, and it seems to answer Freddie Rokem's assertion that questions such as 'how can artistic practice be considered a form of research? and what kind of thinking is produced by such artistic and creative practices?' are among the most pressing in the humanities today (Rokem 2010, 5). The rapid growth of Performance Philosophy as a movement-which has resulted in major international conferences, a burgeoning research network, a dedicated book series, and, now, its very own journal-suggests that this is a prospect that many people, quite understandably, find very enticing.

The underlying concern motivating this paper, and it can only be gestured towards by way of conclusion, is that this paratactical conjoining of performance with philosophy may, unintentionally, impose restrictions upon performance that negate or compromise its autotelicity, thereby undermining the very principle of performance itself-the principle that, in freeing performance of philosophical conditioning, renders performance most philosophically potent. If the foregoing account of performance is at all credible, this would be an unwitting reiteration, or citation, of the culmination of the ancient quarrel, where the principle of performance was excluded in an act of founding, definitional violence. In light of the recent theoretical efforts to enshrine the principle of performance in an idealised conception of 'literature', any threat of a reiteration of this ancient quarrel might perhaps be framed in terms of a potential quarrel between Performance Philosophy and literature. If, on the other hand, it can be argued that Performance Philosophy imposes no such restrictions, philosophy-or, rather, a philosophical function-being compatible with the principle of performance, then Performance Philosophy might be understood as re-citing the recent but apparently exhausted ideals of the 
theory explosion, substituting 'literature' with 'performance'. This, too, could be construed as (at least having the makings of) a quarrel. But if Performance Philosophy cultivates an awareness of its own genealogies, it could also be an opportunity-a bold and timely counter-textual challenge to the often all-too-vapid post-literary theoretical humanities. Either way, what is clear is that Performance Philosophy, particularly as it inaugurates its own journal-a foundational gesture that, inevitably, evokes disciplinary legitimacy and academic respectability-would perhaps do well to be wary of unwitting citations.

\title{
Notes
}

\begin{abstract}
${ }^{1}$ In fact, translations vary. It is translated in this way in the Oxford edition (Plato 1998, 607b). The Loeb edition renders it: 'there is from of old a quarrel between philosophy and poetry (Plato 1942, 465). In the Cambridge edition, generally favoured in this essay, it is 'a long-standing antagonism between poetry and philosophy' (Plato 2003, 607b).

2 Here we might recall Blanchot's comment that literature 'lay[s] claim not only to the sky, the earth, to the past, the future, to physics and philosophy-this would be little-but to everything, to the whole that acts in every instant and every phenomenon (Novalis)' $(2008,355)$.

3 These lines are taken from the Call for Papers for the Theater, Performance, Philosophy, Conference, which took place in Paris, 26-28 June 2014. An earlier version of this paper was presented there, and I remain grateful to the organisers and participants for their valuable feedback.
\end{abstract}

\section{Works Cited}

Adorno, Theodor W. 1997. Aesthetic Theory. Translated by Robert Hullnot-Kentor. Minneapolis: University of Minnesota Press.

Austin, J.L. 1962. How to Do Things with Words. Oxford: Oxford University Press.

Attridge, Derek. 2002. "Singular Events: Literature, Invention, and Performance." In The Question of Literature: The Place of the Literary in Contemporary Theory, edited by Elizabeth Beaumont Bissell, 48-65. Manchester: Manchester University Press.

Attridge, Derek. 2004. The Singularity of Literature. London: Routledge.

Badiou, Alain. 2014. The Age of the Poets: And Other Writings on Twentieth-Century Poetry and Prose. Translated by Bruno Bosteels. London: Verso.

Barthes, Roland. (1973) 1998. The Pleasure of the Text. Translated by Richard Miller. New York: Hill and Wang.

Blanchot, Maurice. (1969) 2008. The Infinite Conversation. Translated by Susan Hanson. Minneapolis and London: University of Minnesota Press.

Butler, Judith. 1997. Excitable Speech: A Politics of the Performative. London: Routledge.

1999. Gender Trouble: Feminism and the Subversion of Identity. London: Routledge.

2011. Bodies that Matter: On the Discursive Limits of 'Sex'. London: Routledge.

Carlson, Marvin. 1996. Performance: A Critical Introduction. London: Routledge. 
Constantine, David. 2013. Poetry. Oxford: Oxford University Press.

Culler, Jonathan. 2000. "Philosophy and Literature: The Fortunes of the Performative." Poetics Today, 21 (3): $503-$ 519. http://dx.doi.org/10.1215/03335372-21-3-503.

Derrida, Jacques. 1976. Of Grammatology. Translated by Gayatri Chakravorty Spivak. Baltimore: Johns Hopkins University Press.

_—_. 1981. Dissemination. Translated by Barbara Johnson. London: Athlone.

___ 1982. Positions. Translated by Alan Bass. Chicago: University of Chicago Press.

_- - 1992. Acts of Literature. Edited by Derek Attridge. New York: Routledge.

___. 1995. On the Name. Translated by David Wood et al. Stanford: Stanford University Press.

___. 2002. Without Alibi. Translated by Peggy Kamuf. Stanford: Stanford University Pres.

Ferrari, G.R.F.. 1989. "Plato and Poetry." In The Cambridge History of Literary Criticism, Vol. I: Classical Criticism, edited by George A. Kennedy, 92-148. Cambridge: Cambridge University Press.

Fischer-Lichte, Erika. 2008. The Transformative Power of Poetry: A New Aesthetics. Translated by Saskya Iris Jain. London: Routledge.

Gasché, Rodolphe. 1997. The Tain of the Mirror: Derrida and the Philosophy of Reflection. Cambridge MA: Harvard University Press.

Hegel, G.W.F.. 1975. Aesthetics: Lectures on Fine Art, Vol. I. Translated by T.M. Knox. Oxford: Oxford University Press.

Jackson, Shannon. 2006. Professing Performance: Theatre in the Academy from Philosophy to Performativity. Cambridge: Cambridge University Press.

Lacoue-Labarthe, Philippe. 1998. Typography: Mimesis, Philosophy, Politics. Edited by Christopher Fynsk. Stanford: Stanford University Press.

Lacoue-Labarthe, Philippe and Jean-Luc Nancy. 1988. The Literary Absolute. Translated by Philip Barnard and Cheryl Lester. Albany: State University of New York Press.

McKenzie, Jon. 2001. Perform or Else: From Discipline to Performance. London: Routledge.

Nagy, Gregory. 2010. "Language and Meter." In A Companion to the Ancient Greek Language, edited by Egbert J. Bakker, 270-287. Chichester UK: Wiley-Blackwell.

Nancy, Jean-Luc. 2006. Multiple Arts: The Muses II. Edited by Simon Sparks. Stanford: Stanford University Press.

Phelan, Peggy. 1996. Unmarked: The Politics of Performance. London: Routledge.

Plato. 1942. The Republic. Translated by Paul Shorey. Cambridge MA: Harvard University Press.

1998. The Republic. Translated by Robin Waterfield. Oxford: Oxford University Press.

2003. The Republic. Translated by Tom Griffith. Cambridge: Cambridge University Press.

Rokem, Freddie. 2010. Philosophers \& Thespians: Thinking Performance. Stanford: Stanford University Press.

Rosen, Stanley. 1993. The Quarrel Between Philosophy and Poetry. London: Routledge.

Schechner, Richard. (1977) 2004. Performance Theory. London: Routledge.

Schlegel, Friedrich. 1971. Friedrich Schlegel's Lucinde and the Fragments. Translated by Peter Firchow. Minneapolis: University of Minnesota Press. 


\section{Biography}

Dr James Corby is a Senior Lecturer and Head of the Department of English at the University of Malta. He has published on literature and philosophy, including articles on romanticism, modernism, phenomenology, politics, and contemporary American literature. He co-edited a volume of essays entitled Style in Theory: Between Literature and Philosophy (Bloomsbury, 2013) and is co-General Editor of the journal CounterText, published by Edinburgh University Press.

(C) 2015 James Corby

cc) (i) (2) Except where otherwise noted, this work is licensed under a Creative Commons Attribution-

cc) NonCommercial-ShareAlike 4.0 International License. 